\title{
I am Here. Where Are All the Other (Straight White) Male Dancers?
}

\author{
Tyler Steven Renfroe \\ College of the Arts, University of Florida
}

Faculty mentor: Joan Frosch, School of Theater and Dance

\begin{abstract}
In the demographics of the American dance world — both professional and social—one group appears to be underrepresented: straight white men. Despite being the second largest group of Americans and overrepresented in many other fields of endeavor, they are proportionally the least represented in social dance. Those straight white men that do dance often began later in their lives than their female peers. Why are so many straight white men missing-in-action on the dance floor; and why, despite boundaries built by social pressure and a lack of enthusiasm or desire to change that fact, do some of "us" slip through and onto the floor? Through oral accounts, personal experience, and literature review, this research examines why so many straight white men refuse to dance, and the motivations of those men that do dance.
\end{abstract}

Keywords: dance, gender, race, sexuality, straight, white, men, social dance

\section{Introduction}

After three years as a dance major at the University of Florida, I have noted men have made up only a small percentage of the dancer population of most dance styles - and, aside from some of my professors - I have been the only self-identified straight male dancer in the program all that time. Why?

"I would stand on the side, watching kids more talented than me tear up the dance floor. I'd feel uncomfortable and awkward just standing around at a dance. But I was far more terrified of being in there attempting to dance myself, so I chose to stay on the sidelines", said my friend Chris Cameron, a 20-year-old straight white man. As I interviewed him about his personal dance history, I realized that I used to be the same way. I, too, feared stepping on the dance floor, but over time my perception of dance began to change. I stopped seeing dance as something to be afraid of, or something I could never be good at. Motivated by a desire to be "cool," I decided to take matters into my own hands and learn to dance. I thought dancing was cool because it seemed like the best dancers at parties were also the ones with the most friends at school. While 
my intentions for joining dance were not noble, they springboarded me into a rich world of discovery and, ultimately, gave me the courage to major in dance.

I discovered that saying "men do not dance" did not paint the full picture: specifically, straight white men were missing on the dance floor. Between the relative inexperience of many men in dance and the smaller number of male dancers to connect and share experiences with, the dance world can seem like a lonely place for a straight white male dancer. Such issues dissuade straight white men from becoming dancers, perpetuating the cycle.

Yet, some of us slip through and onto the dance floor. I intended to uncover and analyze the roots of this fear of, or aversion to, dance in straight white men and then, with this awareness, tackle those fears and prejudices and help more straight white men feel comfortable and begin to want to start dancing, at least socially. Like in therapy, the first step to solving a problem is identifying it.

\section{Methodology}

The research originated in my self-reflection about the excitement, questions, lack of ease, and, at times, isolation I felt as a male dancer. The technique of autoethnography helped me reflect more meaningfully by seeing my individual struggles and triumphs in the context of American history, culture, and society. For my reflection and writing to become a way of knowing, I also needed to build a framework for my self-reflection.

I used three main avenues: (1) literature review, which gave historical context and precedent for my observations; (2) my first-hand experience in dance classes, rehearsals, dance halls, and clubs in Gainesville, FL, including Boca Fiesta, Rockey's Dueling Piano Bar, and Palamino's, where I observed myself and other men in a natural environment; and (3) collecting the informal oral "dance histories" of six male college-aged friends (ages 20-24), who shared with me their dance experiences ranging from none to over a decade. I asked them about their choices to abstain or participate in dancing, and their reasons why; if they did not dance, why not? And if they did dance, did they have a purpose, or did they dance without intention? I also asked about their futures in dance, and whether they saw themselves beginning, continuing, or ceasing to dance. I found those who never danced and those who aimed to gain attention had similar ideas on what dance was about and were both less likely to dance into adulthood. Those who danced without the idea of others' scrutiny in mind were more likely to dance into adulthood, even if they had not been dancing very long. 


\section{Results}

My research suggests that historical attitudes towards dance both influenced, and were influenced by, laws and social norms set in place, often in the form of restrictions, regulations, and limitations. Those appear to have manifested in the ideologies of not only straight white men, but also in men of other sexualities and ethnicities; ideas of who could or should dance, why we dance, and the role of dance in our lives. In turn, those ideas have shaped why men do not dance, unhealthy motives to dance, and positive motivations to continue dancing.

\section{Saying No to Dance}

Until I was 16, I shied away from dancing. Most of my male friends did not dance, and those that did were so good I felt intimidated to even try to achieve their level of expertise. Those that did not had their own reasons for avoiding dance; I interviewed Jason Powers, a 21-year-old straight white man, who reflected on his high school years, "I didn't see a reason to dance. I already had a steady girlfriend when dances became popular during high school, and she didn't really dance either. I didn't need to pick up a girl, and dancing wasn't a way to please my girlfriend, so I just didn’t dance.” Jason obviously saw dance as a form of courtship, an opportunity to pick up a date, and a precursor to sex.

Jason's idea of thinking harkens back to the attitudes of the late Middle Ages when Christianity frowned upon social dances: the church was concerned that dance led to lust (Jonas 121). Later, in 17th-century France, court and couple dancing became more accepted, even by royalty such as King Louis XIV, but the primary focus was still to find a lover or partner, even if that love existed only on the dance floor (Jonas 79). Personally, I never wanted to use dance to find a partner in high school. At the time, I thought the only way to get to know someone was by speaking with them, and that the nonverbal act of dance would not help.

While interviewing Chris, he recalled a painful reason for not dancing, "It was just something I was terrible at, and I didn't want to give people another thing to make fun of me for. It was like everyone else had either been dancing for years or had decided they weren't going to dance. I didn't want to be the weird dude in the middle ground, who was trying to learn to dance but wasn't cool enough.” For a long time, my thoughts mirrored his. "Coolness," as a social measurement, translated to masculinity, but pinning down how to be cool was difficult; how "coolness" and "masculinity" are defined, as well as their associations, have been in constant 
fluctuation throughout history (Fisher and Shay 4). People who were not inherently cool were ridiculed or labeled homophobic slurs like "fags" and were not likely to get involved in a practice like dance that has its own struggles with conceptions of femininity and homosexuality.

Ironically, ballet began as a male art under Louis XIV. Prejudices against male dancers took firm hold in 19th-century European ballet, with the idea that emotions belonged to the inner self, and outer appearances should be emotionless and inexpressive. By embodying his emotions through dance, the male dancer no longer conformed to masculine ideals, and became effeminate (Albright and Dils 44-48). Being thought of as gay seems to be one of the greatest fears of a contemporary straight white man (Craig 109). Men often choose between two options; they will either dance and be forced to explain and convince others that they are not gay or feminine (Gard 75), or just not dance, and avoid those assumptions in the first place. Chris and I chose the second option. I later changed my mind.

After rock-and-roll lost its popularity in the early 1960's, straight white men began listening to hard rock. Hard rock is a musical style that was designed to be listened to without dancing: the key to truly appreciating hard rock was focusing on the lyrics (Craig 101). At the same time, black and gay people began listening to disco music, and while they argued whether disco belonged to black or queer culture, it was music designed for dancing (Craig 100). Because of this divide in musical tastes, white people felt inadequate and out of place trying to dance in discos, which began to establish the stereotype that white men cannot dance. Even the discos were separated by their patrons; certain discos catered to African Americans, some to queers, and some to "high-class citizens" (Craig 99).

While interviewing my friend Peter Peck, a 24-year-old straight white man, he said his excuse for avoiding dance was not because he was afraid or disinterested, but rather he saw it as something for other people, or people he considered inferior:

"It was for those guys who did that stuff all the time, like the black guys when hip-hop songs came on, or those dudes who knew how to dance with a girl and went out for the slow dance, or the high-class parties. It was easy to spot someone trying to do something they weren't good at, or trying to be something they weren't, like a white guy trying to hip-hop or a nerd looking for a partner. I'm just keeping it real."

Peter saw dance as very segregated and broken into clearly defined sections, a holdover from the disco era. He was also a "cool" person in high school, a rich football star who was popular with guys and girls alike, so he could not empathize with people who felt "uncool" or in need of 
a community. I did not empathize with Peter, but he gave me an up-close experience with someone who thought so differently about dance.

Nowadays interracial dancing is more common, but the exceptions often shine a brighter light on the rule; for example, a black person could waltz, or a white person could breakdance, but they would stick out as an anomaly. Once, I went to Boca Fiesta with mostly African-American friends where we danced in a circle, often taking turns and going one or two at a time. After a while, I got progressively more cheers and requests to go back in, and at one point someone said to me, "Come on, you gotta represent us white dudes!" They appreciated my "coolness" and wanted to see more of my willingness to dance, especially with people who did not look like me. Perhaps they were happy to see me competing with people who are typically the "best" dancers, or maybe they envied my ability to keep up with my friends.

Whether out of disinterest, fear, or a feeling of dance being unnecessary, these straight white male friends had their own reasons for avoiding the dance floor. While Peter was completely blind to it, and Jason had a vague understanding of the feeling, Chris and I fully understood that by not participating in dance, we were both missing out on a feeling of belonging that we craved.

\section{Dancing for the Wrong Reasons}

Once I got to my junior year of high school and prom loomed on the horizon, I decided I did not want to stand on the side and feel extremely awkward anymore. I gave myself one goal, to go into a dance circle, survive and nail a dance for about ten seconds, then get out with my dignity intact, and maybe gain a little "street cred." As Travis Santos, a 22-year-old straight Filipino American male, described in his interview, "I danced because that's what the cool kids did, you know? The ladies loved it, and it gave you that street cred." To Travis, dancing was a way to get popular, and he embraced that. He likened the credit you could gain from dance to that one could get from "playing football, having lots of money, or being really good looking." He is far from the first to relate dance to sports to prove its masculinity; Gene Kelly created a program broadcast in 1958 called "Dancing_A Man's Game," in which he compared dance to several other popular sports considered masculine, like football, boxing, and baseball, among others. He rationalized why men in dance wore tights, described them as "uniforms, worn by men, who like gymnasts and divers will be judged on the basis of the lines they create with their bodies" (Craig 81; Fisher and Shay 99). Another example was Vaslav Nijinsky’s 1913 ballet Jeux, a ballet about 
sports, specifically tennis, with sexual subtexts between a male and two females (Jonas 218; Fisher and Shay 93).

Travis also danced to attract women, obviously an idea common to more than just straight white men. When I went to Rockey's Dueling Piano Bar, I noticed that the only other men dancing, regardless of color, were either partnering or dancing near women. The rest sat at their tables or stood with drinks in hand, refusing to dance.

When asked if Travis would continue to dance, he replied:

"I stopped dancing regularly a while ago. Once I had my cred, I didn't need to dance all the time to prove it...that's weird to think about, actually. But yeah, once I didn't need to dance to be cool, I kind of stopped. I'll still bust a move at a party every now and then, but once I get tired of partying, it'll likely be the end of dancing for me."

Dancing to improve social status, to find a date, or to please some expectation, is certainly a reason some men dance but may prove to be an unsustainable motivation; eventually men mature and are not as focused on juvenile things like being "cool."

\section{Dancing with a Healthy Mindset}

I found reasons people did not dance and I found unsustainable reasons people danced, but I had yet to figure out a healthy mindset to have about dance. I turned to friends who planned on dancing into the future to see what kept them interested in dance. Mark Rew, a 22-year-old straight white man, has danced for 11 years and plans on dancing in some capacity in the future. In his interview, Mark explained:

"Ballroom dances were my thing. Dances like the waltz, swing dance, even some salsa; that was my interest...I started dating my girlfriend of seven years, and one of the driving forces in our relationship, at least early on, was our shared love for these ballroom dances. We'd take classes together, then kill the slow dances at prom and stuff."

Mark said dancing made him feel "classy, cultured, and connected to history, each other, and the people around us at formal events." He did not dance to prove something or to find a partner; he danced to feel part of a community, both historically and in the present. Something we have in common is that the show Dancing with the Stars sparked our interest in dance. Dancing with the Stars has returned ballroom dance to the widespread popularity it once had in the early 20thcentury, combining traditional dance styles with pop culture icons like David Hasselhoff to pique 
interest in dance in non-dancers like myself (Fisher and Shay 102). Ballroom dances were characterized by men leading their partner, suggesting a sense of power and dominance associated with masculinity (Jonas 126). However, Mark found a motivation other than promoting his masculinity — he used these dances to integrate and identify himself within a community.

My friend Harry North, a 21-year-old straight African American man, seemed to have the strongest grasp of the purpose of dance. He danced with all his friends and learned all the popular dances, but it was never about popularity or fame for him; as he explained in his interview:

"I'd dance at parties [without] an end goal in mind when I hit the floor. I was just there to have fun and dance with my friends! I could tell that some people liked me better or thought I was cool because I was good at dancing, but that was never my reason for dancing. Rather than showing off, I really wanted to move and have fun with my friends."

Harry started dancing younger than most of my other friends. He was breakdancing, or bboying, at the age of ten. In b-boying, dance is framed as a battle (Craig 8), so the aspects of competition, athleticism, and the appearance of being simultaneously technically sound and improvisational deter the dance from appearing as a show, but instead to defeat and show up an opponent (Craig 191). Even when women breakdance, the dance is still seen as masculine (Craig 118). Despite b-boying being such an aggressive and competitive dance form, Harry formed friendships and community. He started dancing with a traditionally masculine style but found a wholesome purpose to dance. Of the six friends who shared their history with me, Harry's view of dance aligned the most with mine, even though he has been dancing longer than me. We both see dance as a form of community, a way to enjoy the presence and contributions of others and to find an identity for ourselves.

\section{Conclusion}

Talking to my friends, reading the literature of dance history, and reflecting on my own experiences helped me figure out why there are so few straight white male dancers like me, but more importantly why those few of "us" became dancers. Often ignorance, misinformation, and social pressures prevent straight white men from dancing, while only the informed and openminded have the knowledge and courage to pursue dance. Dancing is about more than picking up dates, being cool, and being accepted by others-dance is a beautiful way to connect to different 
cultures and people and create communities, expanding from the self to encompass everyone. It took me a long time to move past worrying about perceptions of me and to focus on the friends and communities that I was making and joining through dance. Unfortunately, all this research can do is present the history and reality of straight white men avoiding dance; it is up to each individual person to accept these truths and allow themselves to be influenced in how they view dance and themselves. However, if this can inspire other anyone else to dance or to support those that do, then I will be honored to have laid the groundwork for dancers who feel alienated in their environment to feel more connected and supported on the dance floor. That feeling of inclusion through dance should be known by everyone, and hopefully this research can spread awareness.

\section{References}

Albright, Ann Cooper, and Ann Dils. Moving History / Dancing Cultures a Dance History Reader. Wesleyan University Press, 2001.

Cameron, Chris. "What is Your History as a Dancer?” Interview. By Tyler Renfroe. Bradenton, FL 22 Dec. 2017.

Craig, Maxine Leeds. Sorry I Don't Dance: Why Men Refuse to Move. Oxford University Press, 2014.

Fisher, Jennifer, and Anthony Shay, editors. When Men Dance: Choreographing Masculinities across Borders. Oxford University Press, 2009.

Gard, Michael. Men Who Dance: Aesthetics, Athletics and the Art of the Masculinity. P. Lang, 2006.

Jonas, Gerald. Dancing: The Pleasure, Power, and Art of Movement. Abrams, 1998.

North, Harry. “What is Your History as a Dancer?” Interview. By Tyler Renfroe. Bradenton, FL 29 Dec. 2017.

Peck, Peter. "What is Your History as a Dancer?” Interview. By Tyler Renfroe. Bradenton, FL 27 Dec. 2017.

Powers, Jason. "What is Your History as a Dancer?” Interview. By Tyler Renfroe. Bradenton, FL 22 Dec. 2017.

Rew, Mark. "What is Your History as a Dancer?” Interview. By Tyler Renfroe. Bradenton, FL 22 Dec. 2017.

Santos, Travis. "What is Your History as a Dancer?” Interview. By Tyler Renfroe. Bradenton, FL 26 Dec. 2017. 